\title{
A study of fungicidal and anti-phenol oxidase activity of some a-amino phosphonate derivatives
}

\author{
Mohsen Abbod ${ }^{1}$, Naser Safaie ${ }^{1 *} \mathbb{D}$, Khodayar Gholivand ${ }^{2}$, Mohammad Mehrabadi ${ }^{3}$, Mahyar Bonsaii ${ }^{4}$ and \\ Ali Asghar Ebrahimi Valmoozi²
}

\begin{abstract}
Background: Developing new pesticides with multi-function may be a suitable strategy to save time and cost and reduce the emergence of resistant strains of pests and pathogens. The organophosphorus derivatives have not been widely used in agriculture as fungicides. In this work, a series of six a-amino phosphonate derivatives were prepared and tested for their fungicidal and anti-phenol oxidase activities.

Results: The prepared compounds revealed a promising anti-fungal activity against Macrophomina phaseolina and Pythium aphanidermatum, especially M4, with MIC of 62 mg/L for M. phaseolina. M4 did not affect the fungus permeability rate of the cell membrane; however, it displayed a significant efficiency on mycelial soluble protein content. $\mathbf{M} \mathbf{4}$ and $\mathbf{M} \mathbf{3}$ with a hydroxyl group on the aniline moiety exhibited an observed anti-phenol oxidase activity. M4 inhibited the enzyme at $1 \mathrm{mg} / \mathrm{mL}$. The DFT theoretical study revealed a significant correlation between the substituents of aniline moiety and the bioactivity of the studied compounds. The negative charge conspicuously influenced the anti-phenol oxidase activity.
\end{abstract}

Conclusions: Our findings suggest the studied compounds as bases to design more effective a-amino phosphonate fungicides with additional anti-phenol oxidase activity.

Keywords: Organophosphorus, Phenol oxidase, DFT, Macrophomina phaseolina, Pythium aphanidermatum

\section{Background}

There is a vast amount of literature that refers to the high expense and time consumption of developing a new antifungal agent [1-3]. The primary defect in using inorganic compounds as fungicides is that they entail a slow disintegration and toxic residues [4]. Historically, most organophosphorus derivatives have been limited to use in agriculture as insecticides, and nowadays, increasing attention is paid to develop new organophosphorus derivatives as fungicides [4]. Cerezin, Kitazin, and

\footnotetext{
*Correspondence: nsafaie@modares.ac.ir

${ }^{1}$ Department of Plant Pathology, Faculty of Agriculture, Tarbiat Modares University, P.O.B. 14115-336, Tehran, Iran

Full list of author information is available at the end of the article
}

Pyrazophos are examples of the few organophosphorus compounds which are used as fungicides [4].

Phenol oxidase (PO) interferes with several biological pathways in insects like melanization and sclerotization cascades [5-9]; also, it is considered a critical defense tool against pathogens attack [6]. Therefore, inhibition of PO may serve as a good strategy for insects control by making their immune system feeble against pathogens [10].

Several studies have been carried out on the biological activity of $\alpha$-amino phosphonate derivatives [11-13]. The similarity between $\alpha$-amino-phosphonic acid and its ester derivatives with natural amino acids has made it possible to use them as drugs to inhibit the activity of some enzymes $[14,15]$. 
The present paper aims to introduce a series of $\alpha$-amino phosphonate derivatives with both antifungal and antiphenol oxidase activity. The fungicidal activity was assayed against two important plant pathogens belong to true fungi and Oomycetes (Macrophomina phaseolina and Pythium aphanidermatum). Also, the PO inhibitory activity was investigated against the Galleria mellonella PO enzyme. The density functional theory calculations were used to explain their bioactivities.

\section{Materials and methods}

\section{Chemicals}

All chemicals and solvents were purchased from Sigma Chemicals (Sigma-Aldrich, Steinheim, Germany). Thiophanate-methyl 70\% WP fungicide was obtained from commercial sources.

\section{General procedures for synthesis a-amino phosphonate derivative}

Kabachnike Fields reaction and Pudovik reaction are the most versatile methods for preparing $\alpha$-amino phosphonate derivative; these methods are considered useful pathways for prepare the construction of $\mathrm{P}-\mathrm{C}-\mathrm{N}$ bonds $[16,17]$. The first step of our procedures was refluxing equimolar amounts $(10 \mathrm{mmol})$ of benzaldehyde and aniline derivatives at $70{ }^{\circ} \mathrm{C}$ for $8 \mathrm{~h}$ in the presence of tetrahydrofuran (THF). After the reacting mixture was cooled to room temperature, the diethyl phosphite $(10 \mathrm{mmol})$ was added to the prepared imine and continue to reflux the mixture for another $18-24 \mathrm{~h}$ to obtain the final compound. The precipitate was filtered, and after evaporating the solvent the product was washed with water (Fig. 1).
All synthesized compounds were elucidated based on the IR and NMR $\left({ }^{1} \mathrm{H},{ }^{13} \mathrm{C}\right.$, and $\left.{ }^{31} \mathrm{P}\right)$ spectroscopy.

IR spectra ( $\mathrm{KBr}$ pellets) were obtained with a Shimadzu, IR-60 model spectrometer. ${ }^{1} \mathrm{H},{ }^{13} \mathrm{C}$, and ${ }^{31} \mathrm{P}$ NMR spectra were recorded on a Bruker (Avance DRS) $500 \mathrm{MHz}$ spectrometer and chemical shifts were determined relative to TMS and $85 \% \mathrm{H}_{3} \mathrm{PO}_{4}$, respectively, as external standards. Elemental analysis was performed on a Flash EA 1112 Thermo Finnigan instrument. Melting points were determined on an Electrothermal IA 9100 digital melting point apparatus.

\section{M1; Diethyl(2-chlorophenyl)(2-chlorophenylamino) methylphosphonate}

Mp: $110-112 \quad{ }^{\circ} \mathrm{C}$. Light yellow powder, ${ }^{1} \mathrm{H}$ NMR (500.13 MHz, d-DMSO, ppm): $\delta=1.25\left(\mathrm{~m}, 6 \mathrm{H}, \mathrm{CH}_{3}\right)$, $4.10\left(\mathrm{~m}, 4 \mathrm{H}, \mathrm{CH}_{2}\right), 6.96-8.44(\mathrm{~m}, 8 \mathrm{H}, \mathrm{Ph}), 8.23(\mathrm{~m}, 1 \mathrm{H}$, CH-P), $10.40(\mathrm{~N}-\mathrm{H}) .{ }^{13} \mathrm{C}$ NMR (125.77 MHz, d-DMSO, ppm)): $\delta=29.7\left(\mathrm{~s}, 2 \mathrm{C}, \mathrm{CH}_{3}\right), 46.4\left(\mathrm{~d}, 2 \mathrm{C}, \mathrm{CH}_{2}\right), 61.5$ (s, 1C, CH-P), 113-135.1 ( $\left.\mathrm{C}_{\mathrm{Ph}}\right), 152.7\left(\mathrm{C}_{\text {ipso-CH }}\right), 158.6$ $\left(\mathrm{C}_{\text {ipso-NH }}\right), 189 .\left(\mathrm{C}_{\mathrm{Cl}}\right) .{ }^{31} \mathrm{P}$ NMR $(202.46 \mathrm{MHz}, \mathrm{d}-\mathrm{DMSO}$, ppm): $\delta=0.29 \mathrm{ppm}$. IR data $\left(\mathrm{KBr}, \mathrm{cm}^{-1}\right): 3437\left(\mathrm{v}_{\mathrm{N}-\mathrm{H}}\right)$; $3059 \mathrm{w}\left(\mathrm{CH}_{\mathrm{Ar}}\right) ; 2922 \mathrm{~s}\left(\mathrm{CH}_{\text {Aliph }}\right) ; 1615 \mathrm{~s}\left(\mathrm{v}_{\mathrm{Ar}}\right) ; 1459 \mathrm{~s}$ $\left(v_{\mathrm{Ar}}\right) ; 1266 \mathrm{~s}\left(\mathrm{v}_{\mathrm{P}=\mathrm{O}}\right) ; 1043 \mathrm{~s}\left(\mathrm{v}_{\mathrm{P}-\mathrm{O}}\right)$. Anal. calcd. for $\mathrm{C}_{17} \mathrm{H}_{20} \mathrm{Cl}_{2} \mathrm{NO}_{3} \mathrm{P}: \mathrm{C}, 52.59 ; \mathrm{H}, 5.19 ; \mathrm{N}, 3.61 \%$. Found: C, 52.83; H, 5.42; N, 3.37\%.

M2; Diethyl(2,4-dichlorophenyl)(2,4-dichlorophenylamino) methylphosphonate

Mp: $130-133{ }^{\circ} \mathrm{C}$. Light yellow powder. ${ }^{1} \mathrm{H}$ NMR (500.13 MHz, d-DMSO, ppm): $\delta=1.24\left(\mathrm{~m}, 6 \mathrm{H}, \mathrm{CH}_{3}\right)$, $4.01\left(\mathrm{~m}, 4 \mathrm{H}, \mathrm{CH}_{2}\right), 6.59-7.78(\mathrm{~m}, 6 \mathrm{H}, \mathrm{Ph}), 8.13(\mathrm{~m}, 1 \mathrm{H}$,

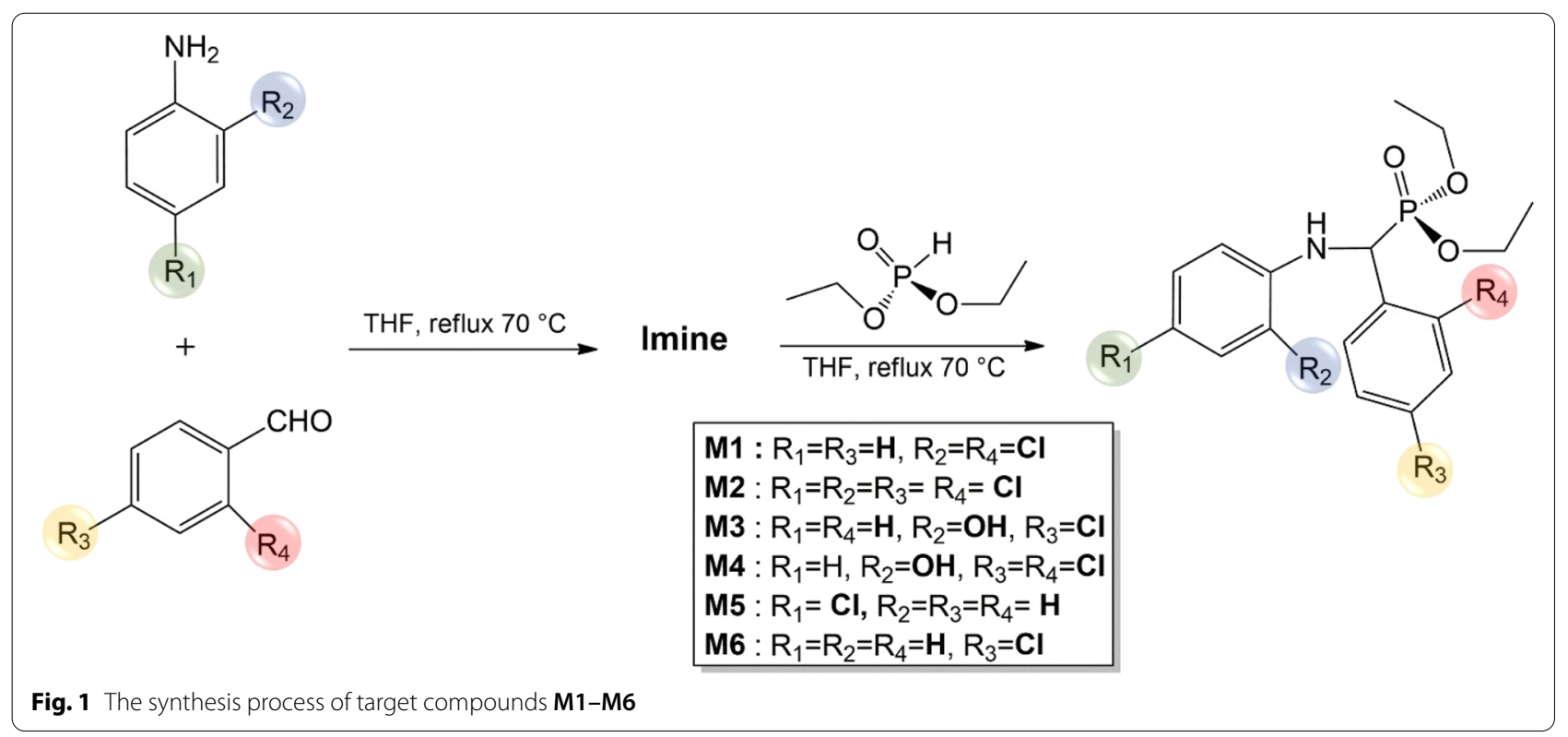


CH-P), $10.31(\mathrm{~N}-\mathrm{H}) .{ }^{13} \mathrm{C}$ NMR (125.77 MHz, d-DMSO, ppm)): $\delta=29.7\left(\mathrm{~s}, 2 \mathrm{C}, \mathrm{CH}_{3}\right), 46.4\left(\mathrm{~s}, 2 \mathrm{C}, \mathrm{CH}_{2}\right), 61.5$ (m, 1 C, CH-P), 113-135.5 ( $\left.\mathrm{C}_{\mathrm{ph}}\right), 157.7\left(\mathrm{C}_{\mathrm{ipso}-\mathrm{CH}}\right), 158.6$ $\left(\mathrm{C}_{\mathrm{ipso-NH}}\right), 191.5\left(\mathrm{C}_{\mathrm{Cl}}\right) \cdot{ }^{31} \mathrm{P}$ NMR $(202.46 \mathrm{MHz}, \mathrm{d}-\mathrm{DMSO}$, ppm): $\delta=0.34 \mathrm{~s}\left(\mathrm{~d},{ }^{2} J_{\mathrm{P}-\mathrm{H}}=11.9 \mathrm{~Hz}\right), \mathrm{ppm}$. IR data $(\mathrm{KBr}$, $\left.\mathrm{cm}^{-1}\right)$ : $3339\left(\mathrm{~m} \mathrm{v}_{\mathrm{N}-\mathrm{H}}\right) ; 2982 \mathrm{~s}\left(\mathrm{CH}_{\mathrm{Ar}}\right) ; 2922 \mathrm{~s}\left(\mathrm{CH}_{\mathrm{Aliph}}\right)$; 1617; $1583\left(\mathrm{v}_{\mathrm{Ar}}\right) ; 1259 \mathrm{~s}\left(\mathrm{v}_{\mathrm{P}=\mathrm{O}}\right) ; 1037 \mathrm{~s}\left(\mathrm{v}_{\mathrm{P}-\mathrm{O}}\right)$. Anal. calcd. for $\mathrm{C}_{17} \mathrm{H}_{18} \mathrm{Cl}_{4} \mathrm{NO}_{3} \mathrm{P}$ : C, 44.67; H, 3.97; N, 3.06\%. Found: C, $44.35 ; \mathrm{H}, 3.84 ; \mathrm{N}, 3.17 \%$

\section{M3; Diethyl(4-chlorophenyl)(2-hydroxyophenylamino) methylphosphonate}

Mp: $102-106{ }^{\circ} \mathrm{C}$. Brownish-yellow powder. ${ }^{1} \mathrm{H}$ NMR (500.13 MHz, d-DMSO, ppm): $\delta=1.34\left(\mathrm{~m}, 6 \mathrm{H}, \mathrm{CH}_{3}\right)$, 4.12(m, $\left.4 \mathrm{H}, \mathrm{CH}_{2}\right), 6.43-7.46(\mathrm{~s}, 1 \mathrm{H}, \mathrm{OH}), 0.6 .43-8.64$ (m, 8H, ph), 8.03 (m, 1H, CH-P), $9.97(\mathrm{~N}-\mathrm{H}) .{ }^{13} \mathrm{C}$ NMR (125.77 MHz, d-DMSO, ppm)): $\delta=39.9\left(\mathrm{~s}, \mathrm{CH}_{3}\right), 45.5$ (s, $\left.\mathrm{CH}_{2}\right), 64.9(\mathrm{~m}, 1 \mathrm{C}, \mathrm{CH}-\mathrm{P}), 115.6-138\left(\mathrm{C}_{\mathrm{Ph}}\right), 158.6$ $\left(\mathrm{C}_{\text {ipso-CH}}\right), 156.1\left(\mathrm{C}_{\text {ipso-NH}}\right), 173.3\left(\mathrm{C}_{\mathrm{OH}}\right), 190.9\left(\mathrm{C}_{\mathrm{Cl}}\right) \cdot{ }^{31} \mathrm{P}$ NMR (202.46 MHz, d-DMSO, ppm): $\delta=0.136 \mathrm{~s}$ (d, $\left.{ }^{2} J_{\mathrm{P}-\mathrm{H}}=11.8 \mathrm{~Hz}\right)$, ppm. IR data $\left(\mathrm{KBr}, \mathrm{cm}^{-1}\right): 3379 \mathrm{~b}\left(\mathrm{v}_{\mathrm{O}-}\right.$ $\left.{ }_{\mathrm{H}}\right) ; 3304 \mathrm{~m}\left(\mathrm{v}_{\mathrm{N}-\mathrm{H}}\right) ; 3042 \mathrm{w}\left(\mathrm{CH}_{\mathrm{Ar}}\right) ; 2925 \mathrm{w}\left(\mathrm{CH}_{\mathrm{Aliph}}\right)$; $1623 \mathrm{~s} ; 1582 \mathrm{~s}\left(\mathrm{v}_{\mathrm{Ar}}\right) ; 1230 \mathrm{~s} ; 1196 \mathrm{~s}\left(\mathrm{v}_{\mathrm{P}=\mathrm{O}}\right) ; 1084 \mathrm{~s}\left(\mathrm{v}_{\mathrm{P}-\mathrm{O}}\right)$. Anal. calcd. for $\mathrm{C}_{17} \mathrm{H}_{21} \mathrm{ClNO}_{4} \mathrm{P}: \mathrm{C}, 55.22 ; \mathrm{H}, 5.72 ; \mathrm{N}$, $3.79 \%$. Found: C, 55.34; H, 5.80; N, 3.88\%.

\section{M4; Diethyl(2,4-dichlorophenyl)(2-hydroxyophenylamino) methylphosphonate}

Mp: $115-117^{\circ} \mathrm{C}$. Yellow powder. ${ }^{1} \mathrm{H}$ NMR $(500.13 \mathrm{MHz}$, d-DMSO, ppm): $\delta=1.38\left(\mathrm{~m}, 6 \mathrm{H}, \mathrm{CH}_{3}\right), 4.14(\mathrm{~m}, 4 \mathrm{H}$, $\left.\mathrm{CH}_{2}\right), 6.92(\mathrm{~s}, 1 \mathrm{H}, \mathrm{OH}), 8.21(1 \mathrm{H}, \mathrm{CH}-\mathrm{P}), 7.21-7.88(\mathrm{~m}$, 7H, ph), $9.10(\mathrm{~N}-\mathrm{H}),{ }^{13} \mathrm{C}$ NMR (125.77 MHz, d-DMSO, ppm)): $\delta=39.8\left(\mathrm{~s}, 2 \mathrm{C}, \mathrm{CH}_{3}\right), 46.5\left(\mathrm{~s}, 2 \mathrm{C}, \mathrm{CH}_{2}\right), 64.5(\mathrm{~m}, 1$ C, CH-P), 115.3-138.1 $\left(\mathrm{C}_{\text {ph }}\right), 151.9\left(\mathrm{C}_{\text {ipso-CH }}\right), 155.1\left(\mathrm{C}_{\text {ipso- }}\right.$ $\left.{ }_{\mathrm{NH}}\right), 173.0\left(\mathrm{C}_{\mathrm{OH}}\right), 190.9\left(\mathrm{C}_{\mathrm{Cl}}\right) \cdot{ }^{31} \mathrm{P}$ NMR (202.46 MHz, d-DMSO, ppm): $\delta 0.29 \mathrm{~s}\left(\mathrm{~d},{ }^{2} J_{\mathrm{P}-\mathrm{H}}=9.8 \mathrm{~Hz}\right)$, ppm. IR data $\left(\mathrm{KBr}, \mathrm{cm}^{-1}\right): 3461 \mathrm{~m}\left(\mathrm{v}_{\mathrm{O}-\mathrm{H}}\right) ; 3339 \mathrm{~m}\left(\mathrm{v}_{\mathrm{N}-\mathrm{H}}\right) ; 2983: 2920 \mathrm{~m}$ $\left(\mathrm{CH}_{\mathrm{Ar}}\right) ; 3076 \mathrm{w}\left(\mathrm{CH}_{\text {Aliph }}\right) ; 1475 \mathrm{~s} ; 1616 \mathrm{~s}\left(\mathrm{v}_{\mathrm{Ar}}\right) ; 1258 \mathrm{~s}$ $\left(\mathrm{v}_{\mathrm{P}=\mathrm{O}}\right) ; 1095 \mathrm{~s}\left(\mathrm{v}_{\mathrm{P}-\mathrm{O}}\right) .1475: 1616 \mathrm{~s}\left(_{\mathrm{C}=\mathrm{C}}\right)$. Anal. calcd. for $\mathrm{C}_{17} \mathrm{H}_{20} \mathrm{Cl}_{2} \mathrm{NO}_{4} \mathrm{P}$ : C, 50.51; H, 4.99; N, 3.47\%. Found: C, $50.78 ; \mathrm{H}, 4.85 ; \mathrm{N}, 3.36 \%$

\section{M5; Diethyl(phenyl)(4-chlorophenylamino) methylphosphonate}

Mp: $84-87 \quad{ }^{\circ} \mathrm{C}$. Dark yellow powder. ${ }^{1} \mathrm{H} \quad \mathrm{NMR}$ (500.13 MHz, d-DMSO, ppm): $\delta=1.24\left(\mathrm{~m}, 6 \mathrm{H}, \mathrm{CH}_{3}\right)$, 4.01(m 4H, $\left.\mathrm{CH}_{2}\right), 6.64,7.75(\mathrm{~m}, 9 \mathrm{H}, \mathrm{Ph}), 8.03(\mathrm{~m}, 1 \mathrm{H}$, $\mathrm{CH}-\mathrm{P}), 8.53(\mathrm{~N}-\mathrm{H}) .{ }^{13} \mathrm{C}$ NMR (125.77 MHz, d-DMSO, ppm)): $\delta=22.7\left(\mathrm{~s}, 2 \mathrm{C}, \mathrm{CH}_{3}\right), 29.72\left(\mathrm{~s}, 2 \mathrm{C}, \mathrm{CH}_{2}\right), 77.04$ (m, 1 C, CH-P), 120.8-137.3 $\left(\mathrm{C}_{\mathrm{ph}}\right), 151.68\left(\mathrm{C}_{\mathrm{ipso}-\mathrm{CH}}\right)$, $158.8\left(\mathrm{C}_{\text {ipso-NH }}\right), 191.8\left(\mathrm{C}_{\mathrm{Cl}}\right) .{ }^{31} \mathrm{P}$ NMR $(202.46 \mathrm{MHz}$, d-DMSO, ppm): $\delta=0.28 \mathrm{~s}\left(\mathrm{~d},{ }^{2} J_{\mathrm{P}-\mathrm{H}}=13.1 \mathrm{~Hz}\right), \mathrm{ppm}$. IR data $\left(\mathrm{KBr}, \mathrm{cm}^{-1}\right)$ : 3330b $\left(\mathrm{v}_{\mathrm{N}-\mathrm{H}}\right) ; 3266 \mathrm{~b}\left(\mathrm{CH}_{\mathrm{Ar}}\right) ; 3202$
$\left(\mathrm{CH}_{\text {Aliph }}\right) ; 1610 \mathrm{~s}-1630\left(\mathrm{v}_{\mathrm{Ar}}\right) ; 1201 \mathrm{~m}\left(\mathrm{v}_{\mathrm{P}=\mathrm{O}}\right) ; 1088 \mathrm{~m}\left(\mathrm{v}_{\mathrm{P}-}\right.$ o). Anal. calcd. for $\mathrm{C}_{17} \mathrm{H}_{21} \mathrm{ClNO}_{3} \mathrm{P}: \mathrm{C}, 57.71 ; \mathrm{H}, 5.98 ; \mathrm{N}$, $3.96 \%$. Found: C, $57.59 ; \mathrm{H}, 5.85 ; \mathrm{N}, 3.98 \%$

\section{M6; Diethyl(4-chlorophenyl)(phenylamino) methylphosphonate}

Mp: 87-90 ${ }^{\circ} \mathrm{C}$. Yellow powder. ${ }^{1} \mathrm{H}$ NMR $(500.13 \mathrm{MHz}$, d-DMSO, ppm): $\delta=1.37\left(\mathrm{~m}, 6 \mathrm{H}, \mathrm{CH}_{3}\right), 4.16(\mathrm{~m}, 4 \mathrm{H}$, $\left.\mathrm{CH}_{2}\right), 7.10-7.79$ (m, 9H, ph), 8.11 (1H, CH-P), 8.45 $(\mathrm{N}-\mathrm{H}) .{ }^{13} \mathrm{C}$ NMR (125.77 MHz, d-DMSO, ppm)): $\delta=16.11\left(\mathrm{~s}, 2 \mathrm{C}, \mathrm{CH}_{3}\right), 30.3\left(\mathrm{~s} 2 \mathrm{C}_{2} \mathrm{CH}_{2}\right), 63.6(\mathrm{~m}, 1 \mathrm{C}$, CH-P), 116.23-150.5 $\left(\mathrm{C}_{\mathrm{ph}}\right), 151.9\left(\mathrm{C}_{\text {ipso-CH }}\right), 156.1\left(\mathrm{C}_{\text {ipso- }}\right.$ $\left.{ }_{\mathrm{NH}}\right), 160.72\left(\mathrm{C}_{\mathrm{Cl}}\right) .{ }^{31} \mathrm{P}$ NMR (202.46 $\mathrm{MHz}, \mathrm{d}-\mathrm{DMSO}$, ppm): $\delta=0.30\left(\mathrm{~d},{ }^{2} J_{\mathrm{P}-\mathrm{H}}=12.8 \mathrm{~Hz}\right), \mathrm{ppm}$. IR data $(\mathrm{KBr}$, $\left.\mathrm{cm}^{-1}\right)$ : 3376b; $\left(\mathrm{v}_{\mathrm{N}-\mathrm{H}}\right)$; $2978 \mathrm{w}\left(\mathrm{CH}_{\mathrm{Ar}}\right) ; 2930 \mathrm{~b}\left(\mathrm{CH}_{\text {Aliph }}\right)$; $1491 \mathrm{~m}-1626 \mathrm{~m}\left(\mathrm{v}_{\mathrm{Ar}}\right) ; 1245 \mathrm{~s}\left(\mathrm{v}_{\mathrm{P}=\mathrm{O}}\right) ; 1084 \mathrm{~s}\left(\mathrm{v}_{\mathrm{P}-\mathrm{O}}\right)$.

\section{Fungal and oomycete strains}

We used Macrophomina phaseolina Mph44, which was isolated and identified previously, and its high virulence was confirmed [18]. It was originally obtained from melons with charcoal rot disease in Khorasan province. Pythium aphanidermatum 8P isolate was used due to its high pathogenicity [19]. It was isolated from sugar beet fields of west Azarbaijan province, Iran [19].

\section{Fungicidal activity study}

Mycelial growth and microsclerotia production inhibition assays

To investigate the fungicidal activity of the synthesized compounds, increasing concentrations were tested against the fungus using the poison food technique [20]. Briefly, different concentrations of the compounds were added to Petri plates containing a Potato Dextrose Agar (PDA) medium, then a mycelial disc (6 mm diameter, 3 to 5 days old) of the fungus placed in the center of the plate, and incubated at $27{ }^{\circ} \mathrm{C}$ for 4 days. The mycelial growth inhibition was calculated using Eq. (1) [21, 22].

$$
\text { Mycelial growth inhibition (MGI)\% }=\left[\frac{\mathrm{C}-\mathrm{T}}{\mathrm{C}}\right] \times 100
$$

In which $C$ is the diameter $(\mathrm{mm})$ of the fungal colony in control, and $T$ is the diameter $(\mathrm{mm})$ of the fungal colony in the presence of the tested compound. Thiophanatemethyl 70\% WP was used as a positive control.

\section{Cell membrane relative permeability rate}

The relative permeability rate of the cell membrane was evaluated using the procedures of Kobno et al. [23] with some modifications. Five mycelial discs ( 7 days old) of the fungus were incubated into Czapek-Dox Broth medium for 5 days. Then the harvested mycelia were washed with 
double distilled water and $0.5 \mathrm{~g}$ of the mycelia was placed in a $50 \mathrm{~mL}$ tube containing $150 \mu \mathrm{g} / \mathrm{mL}$ of each tested compound. The conductivities were sequentially measured at $0\left(J_{0}\right), 5,10,30,60,180,360 \mathrm{~min}\left(J_{1}\right)$. After boiling which was followed by cooling, the conductivity $\left(J_{2}\right)$ was measured. The permeability $(P \%)$ were calculated by the formula: $P \%=\left[\left(J_{1}-J_{0}\right) /\left(J_{2}-J_{0}\right)\right] \times 100[23]$.

\section{Preparing of the mycelium crude extract}

The mycelium crude extract was prepared using the procedures of Wu et al. (2005) [24] with some modifications. Five mycelial discs (6 mm diameter, 7 days old) of the fungus were placed in an Erlenmeyer flask containing $90 \mathrm{~mL}$ of sterilized Czapek-Dox Broth medium and incubated in a rotary shaker $\left(120 \mathrm{rpm}, 27^{\circ} \mathrm{C}\right.$ for 15 days), then the tested compound was dripped into the culture medium at a concentration of $100 \mu \mathrm{g} / \mathrm{mL}$. The mycelium was filtered, collected orderly at $0.5,1,3,6,12$, and $24 \mathrm{~h}$ and washed by water. Water was soaked with a filter paper, and the dried mycelium was weighed, and preserved at $-20{ }^{\circ} \mathrm{C}$. $0.25 \mathrm{~g}$ of the dry mycelium was mixed with Tris- $\mathrm{HCl}$ buffer $(2 \mathrm{~mL}, 50 \mathrm{mmol} / \mathrm{L}, \mathrm{pH}=7)$ in the mortar, triturated into paste quickly, and then centrifuged at $4{ }^{\circ} \mathrm{C}$ and $15,000 \mathrm{~g}$ for $30 \mathrm{~min}$. The clear upper layer was preserved at $-20^{\circ} \mathrm{C}$. Every treatment had three repetitions [24].

\section{Mycelial soluble protein content}

The mycelial soluble protein content was evaluated using a modified method of Hatada et al. [25]. $150 \mu \mathrm{L}$ of the mycelial extract was mixed with Coomassie brilliant blue G-250 solution ( $3 \mathrm{~mL}$ ), after $5 \mathrm{~min}$, the absorbance value of the mixture was measured at $595 \mathrm{~nm}$. Tris- $\mathrm{HCl}$ buffer served as the control [25].

\section{Anti-phenol oxidase activity}

Phenol oxidase inhibitory activity was measured using Ullah et al. [26] method with some modifications. The Haemolymph of the fifth instar larvae of Galleria mellonella was collected by placing them at $-20{ }^{\circ} \mathrm{C}$ for $10 \mathrm{~min}$. They were surface sterilized with $70 \% \mathrm{EtOH}$, cut at the abdominal prolegs, and blended into a pre-chilled sterile polypropylene tube. Then it diluted with $10 \mathrm{mM}$ phosphate-buffered saline solution and kept on ice. Then it centrifuged at $4{ }^{\circ} \mathrm{C}$ and $15,000 \mathrm{~g}$ for $15 \mathrm{~min}$. The supernatant was collected and used as an enzyme source. Different concentrations of the tested compounds (50, 250, 500 , and $1000 \mu \mathrm{g} / \mathrm{mL}$ dissolved in DMSO) were prepared, then phenol oxidase (PO) inhibition was determined using a L-3,4-dihydroxyphenylalanine (L-DOPA) substrate-based assay carried out in a microplate, $100 \mu \mathrm{L}$ of distilled water, $20 \mu \mathrm{L}$ PBS buffer, $20 \mu \mathrm{L}$ of the substrate, $20 \mu \mathrm{L}$ of the tested compound were added to each well then $20 \mu \mathrm{L}$ of the enzyme source was added. The absorbance was detected at $490 \mathrm{~nm}$ for $30 \mathrm{~min}$ [26]. Three replicates were used for each treatment, and Kojic acid was used as a positive control. The tested compounds (50, 250,500 , and $1000 \mu \mathrm{g} / \mathrm{mL}$ dissolved in DMSO) were prepared, then phenol oxidase (PO) inhibition was determined using a L-3,4-dihydroxyphenylalanine (L-DOPA) substrate-based assay carried out in a microplate, $100 \mu \mathrm{L}$ of distilled water, $20 \mu \mathrm{L}$ PBS buffer, $20 \mu \mathrm{L}$ of the substrate, $20 \mu \mathrm{L}$ of the tested compound were added to each well then $20 \mu \mathrm{L}$ of the enzyme source was added. The absorbance was detected at $490 \mathrm{~nm}$ for $30 \mathrm{~min}$ [26]. Three replicates were used for each treatment, and Kojic acid was used as a positive control.

\section{Density functional theory (DFT) analysis}

All the calculations were carried out using density functional theory (DFT) as implemented in the Gaussian 09 package [27] Geometries were optimized using the B3LYP functional with the 6-31 $\mathrm{G}^{* * *}$ basis set. The energies were reevaluated by additional single point calculations at each optimized geometry using the $6-311 \mathrm{G}^{* *}++$ basis set. [27-30]. The natural population was calculated using the NBO program (NBO Version 3.1) [31].

\section{Statistical analysis}

The experiments were carried out in a completely random design with three replications. Data were analyzed using analysis of variance (ANOVA), and mean comparison was conducted by the least significant difference (LSD) using SAS software [32] using a personal computer. The results are presented as means and their standard errors $(\mathrm{SE})$.

\section{Results and discussion Anti-fungal activity}

The synthesized compounds were evaluated for their fungicidal activity against two important plant pathogens, including Macrophomina phaseolina from the true fungi and Pythium aphanidermatum from the Oomycetes. The true fungi and Oomycetes differ from each other in several points [1]. Thus, using these pathogens in our assays may help to have a clear view of how these compounds can affect the selected pathogens.

The compounds were tested at concentrations up to $400 \mathrm{mg} / \mathrm{L}$. M1 and M2 showed significant activity against both pathogens at all of the tested concentrations. M4 and M3 exhibited full inhibition of $M$. phaseolina at concentrations from 400 to $100 \mathrm{mg} / \mathrm{L}$. Moreover, M4 inhibited the growth of $P$. aphanidermatum at any of the tested concentrations; thus, we have tested these compounds at lower doses (Table 1). 
Table 1 Growth inhibition values of the tested compounds

\begin{tabular}{|c|c|c|c|c|c|c|c|}
\hline Plant pathogens & $\begin{array}{l}\text { Concentration } \\
\text { (mg/L) }\end{array}$ & M1 & M2 & M3 & M4 & M5 & M6 \\
\hline \multirow[t]{7}{*}{ M. phaseolina } & 400 & $100 \pm 0^{*}$ & $100 \pm 0$ & $100 \pm 0$ & $100 \pm 0$ & $42 \pm 2.36$ & $34 \pm 2.08$ \\
\hline & 300 & $94 \pm 1.52$ & $96 \pm 1$ & $100 \pm 0$ & $100 \pm 0$ & 0 & 0 \\
\hline & 200 & $90 \pm 1$ & $95 \pm 1.5$ & $100 \pm 0$ & $100 \pm 0$ & 0 & - \\
\hline & 150 & $85 \pm 3.06$ & $91 \pm 1.32$ & $96 \pm 2.64$ & $100 \pm 0$ & - & - \\
\hline & 100 & $62.5 \pm 2.3$ & $82.5 \pm 1.44$ & $90 \pm 1.3$ & $100 \pm 0$ & - & - \\
\hline & 50 & - & - & $55 \pm 3.05$ & $90 \pm 2$ & - & - \\
\hline & 25 & - & - & - & $63 \pm 1.15$ & - & - \\
\hline \multirow[t]{6}{*}{ P. aphanidermatum } & 400 & $100 \pm 0$ & $100 \pm 0$ & $100 \pm 0$ & $100 \pm 0$ & $90 \pm 2.51$ & 0 \\
\hline & 300 & $90 \pm 1.73$ & $100 \pm 0$ & $100 \pm 0$ & $100 \pm 0$ & 0 & 0 \\
\hline & 200 & $67.5 \pm 1.32$ & $95 \pm 1$ & $100 \pm 0$ & $100 \pm 0$ & 0 & - \\
\hline & 100 & $23 \pm 1.52$ & $93 \pm 0.76$ & $35 \pm 4.04$ & $100 \pm 0$ & - & - \\
\hline & 50 & - & - & 0 & $25 \pm 1.81$ & - & - \\
\hline & 25 & - & - & - & $20 \pm 1.52$ & - & - \\
\hline
\end{tabular}

*Inhibition was measured experimentally (mean \pm SE), replicate number $n=3$

-:The compound was tested at this concentration

The MIC of M4 was about $62 \mathrm{mg} / \mathrm{L}$ for $M$. phaseolina and less than $100 \mathrm{mg} / \mathrm{L}$ for $P$. aphanidermatum, while M3 had MICs about 175 and $200 \mathrm{mg} / \mathrm{L}$. M5 displayed $90 \% \pm 2.51$ inhibition of $P$. aphanidermatum at $400 \mathrm{mg} / \mathrm{L}$, while $\mathbf{M 6}$ showed weaker activity against the pathogens compared to other compounds (Table 1). As can be noted from Table 1, there are no significant differences in the fungicidal activity on both $M$. phaseolina and $P$. aphanidermatum. These findings suggest that the tested compounds may interfere with the same targets within the pathogens or might have multiple modes of action. Consequently, future studies are required to understand their mode of action on both True fungi and Oomycetes. All tested compounds showed a level of fungicidal activity against $M$. phaseolina; thus, we studied the impact of different R-substituents on their activity. Figure 1 and Table 1 indicate that all compounds having substituents on both rings (i.e., M1, M2, M3, and M4) showed higher activity. In contrast, the compounds contain only one substituent displayed a weak comparative activity, which implies that both rings and their substituents are essential to improve their fungicidal activity. M5 with a $\mathrm{Cl}$-substituent on the aniline moiety showed higher activity than M6 with Cl-substituent on the phenyl moiety. Additionally, when $\mathrm{OH}$-substituent replaces the $\mathrm{Cl}$ substituent on the aniline moiety as in M3 and M4, we observed a significant increase in the fungicidal activity. Furthermore, having a hydroxyl group on the aniline increased the fungicidal activity more than chlorines. It may suggest that the aniline ring and its substituents have a higher impact on the fungicidal activity than phenyl ring substituents.

\section{The effect on the relative permeability rate of the cell membrane}

The relative permeability rate of the cell membrane of $M$. phaseolina was detected in the presence and absence of M2 and M4 to evaluate the cytotoxic impact of synthesized derivatives at $150 \mu \mathrm{g} / \mathrm{mL}$. In the case of M2, the relative permeability rate of the cell membrane was higher than the control in the first $100 \mathrm{~min}$; however, it was found to be lower than control with a longer treatment time. In contrast, when fungus treated with $\mathbf{M 4}$, the relative permeability rate of the cell membrane was always lower than the control; moreover, within $300 \mathrm{~min}$, it was less than M2-treated fungus and differed after that. The relative permeability rate of thiophanate methyl-treated fungus was always higher than control and other treatments (Fig. 2). It seems that the cell membrane was not affected by $\mathbf{M} \mathbf{2}$ and $\mathbf{M} 4$ compounds, which may decrease the ability of these molecules to inhibit the fungus growth by interfering with the cell membrane.

\section{The effect on mycelial soluble protein content}

The soluble protein content was detected in the presence and absence of the M4 compound at $100 \mu \mathrm{g} / \mathrm{mL}$. Figure 3 displayed that within an hour, the soluble protein content was higher than control, then it dropped in a timedependent manner. It can be seen that the soluble protein content was $19.7 \pm 0.68 \%$ and $25.91 \% \pm 1.89$ lower than the control in 12 and $24 \mathrm{~h}$, respectively; moreover, it was lower than thiophanate methyl-treated fungus after 


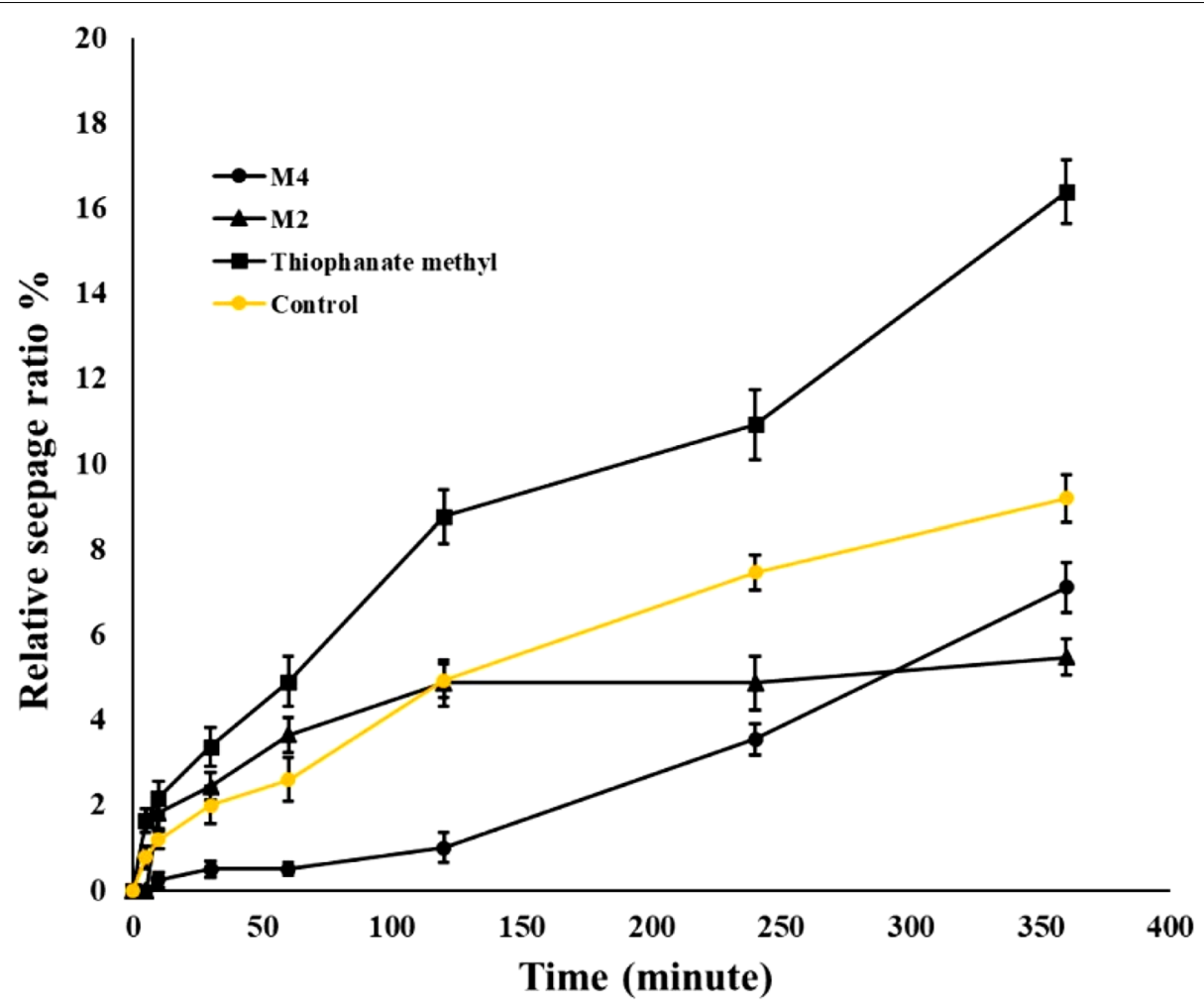

Fig. 2 The effect of compounds $\mathbf{M} \mathbf{2}$ and $\mathbf{M} \mathbf{4}$ on membrane permeability of M. phaseolina at $150 \mu \mathrm{g} / \mathrm{mL}$. The results were compared with control (without compound) at the corresponding period. The error bars represent the mean \pm SE of the three repeats $(P<0.05)$

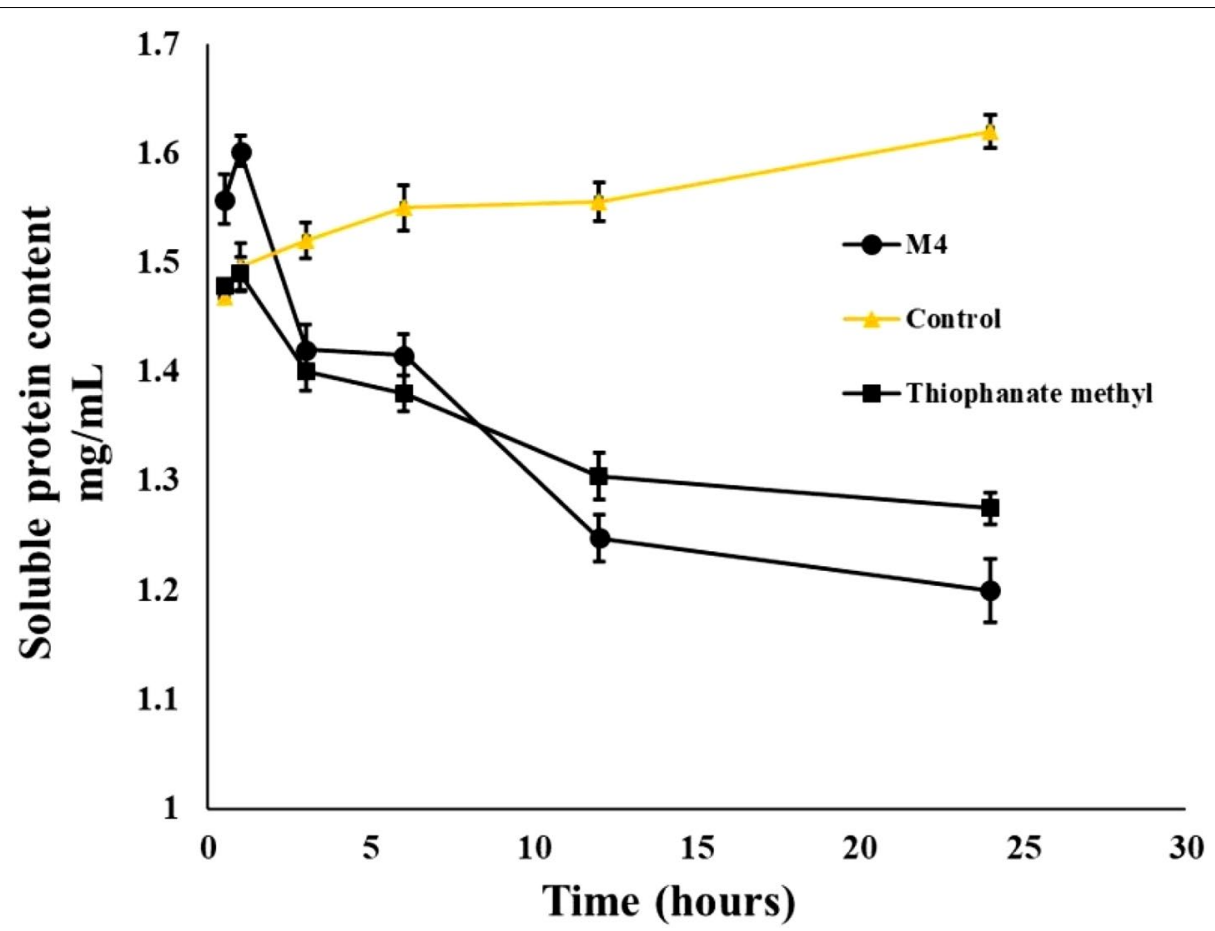

Fig. 3 The effect of compound $\mathbf{M} \mathbf{4}$ on the mycelial soluble protein content of M. phaseolina at $100 \mu \mathrm{g} / \mathrm{mL}$ as compared to control (without compound) at the corresponding period. Thiophanate-methyl 70\% WP was used as positive control. The error bars represent the mean \pm SE of the three repeats $(P<0.05)$ 
$8 \mathrm{~h}$. These results suggest that $\mathbf{M 4}$ may reduce pathogen growth by inhibiting protein synthesis.

\section{Anti-phenol oxidase activity}

The activity of synthesized compounds on the insects immune-associated characteristics was tested on the G. mellonella phenol oxidase enzyme. Both M4 and M3 revealed phenol oxidase inhibitory activity more than kojic acid (Figs. 4, 5). M4 inhibited the enzyme activity by $100 \%$ at $1000 \mu \mathrm{g} / \mathrm{mL}$; also, it showed $86 \% \pm 1.73$ and $73.67 \% \pm 2.02$ of enzyme inhibition at 500 and $250 \mu \mathrm{g} / \mathrm{mL}$, respectively. M3 displayed $34.3 \% \pm 1.2$ to

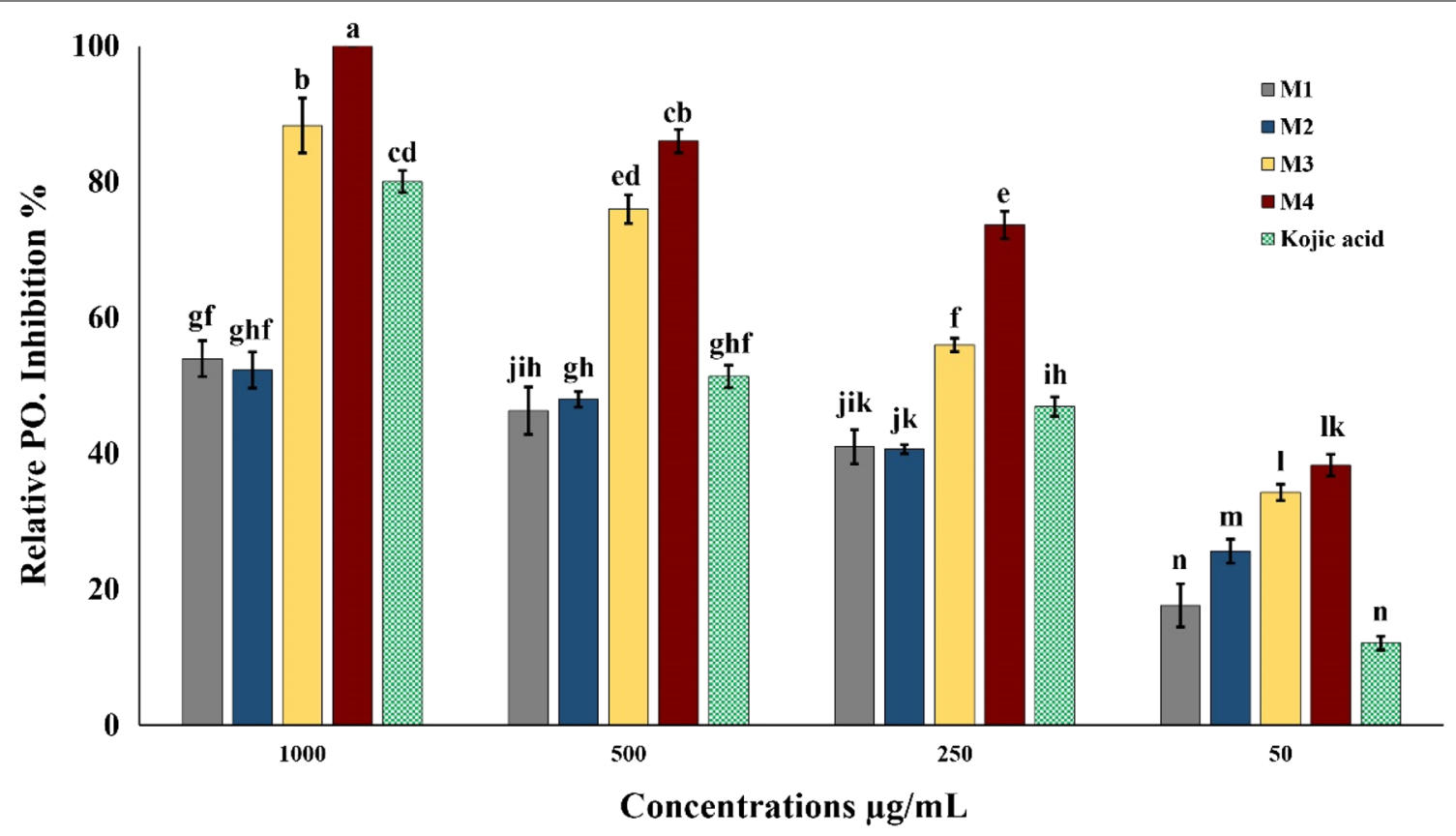

Fig. 4 Phenol oxidase inhibition by increasing concentrations of tested compounds. The treatments compression was done using LSD test based on completely random design. Values are averages of three replications $(n=3)$. The error bars represent the mean \pm SE of the three repeats

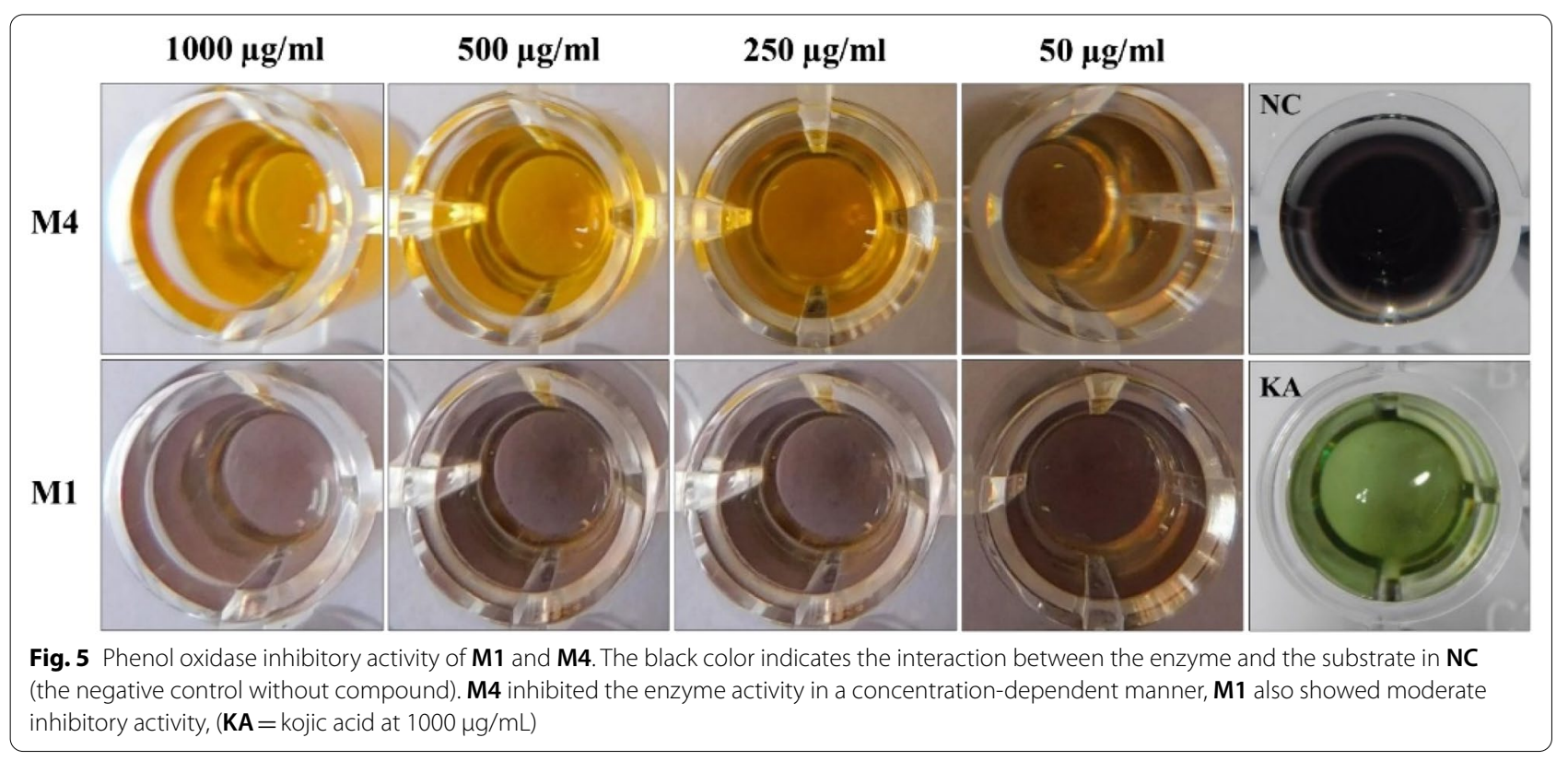


$88.3 \% \pm 4.05$ of enzyme inhibition at 50 to $1000 \mu \mathrm{g} /$ $\mathrm{mL}$. M1 and M2 without $\mathrm{OH}$-substituent on the aniline moiety were less capable than M3 and M4. M1 exhibited $54 \% \pm 2.65$ to $17.67 \% \pm 3.17$ inhibition at 1000 to $50 \mu \mathrm{g} /$ $\mathrm{mL}$, respectively, while $\mathbf{M} 2$ did not exceed $52.3 \% \pm 2.67$ at the highest dose (Fig. 4). The anti-phenol oxidase activity was not significantly affected whether the molecule has one or two Cl-substituents on the phenyl ring; however, it increased considerably by replacing the $\mathrm{Cl}$-substituent with $\mathrm{OH}$-substituent on the aniline moiety. These findings indicate the crucial role of the hydroxyl group in the phenol oxidase inhibitory activity of tested compounds. Phenol oxidase interferes with several biological pathways in insects like melanization and sclerotization cascades [5-9]. By the inhibition of phenol oxidase, our compounds may interfere with the insects immune system and block the melanization process which leads to the weakness of insects defense [5-9].

\section{DFT calculation}

We performed DFT calculations M1-M4, M6, and the phenol oxidase substrate L-DOPA. The plots of the frontier orbitals, their calculated energy, and their natural atomic charge distribution are mentioned in Fig. 6 and Table 2. The Highest Occupied Molecular Orbital (HOMO) and Lowest Unoccupied Molecular Orbital (LUMO) are helpful tools for evaluating the molecules' bioactivity [32-36]. They refer to the parts of the molecules that can interact with the receptors [37]. Figure 6 showed that the HOMO orbital delocalized on the

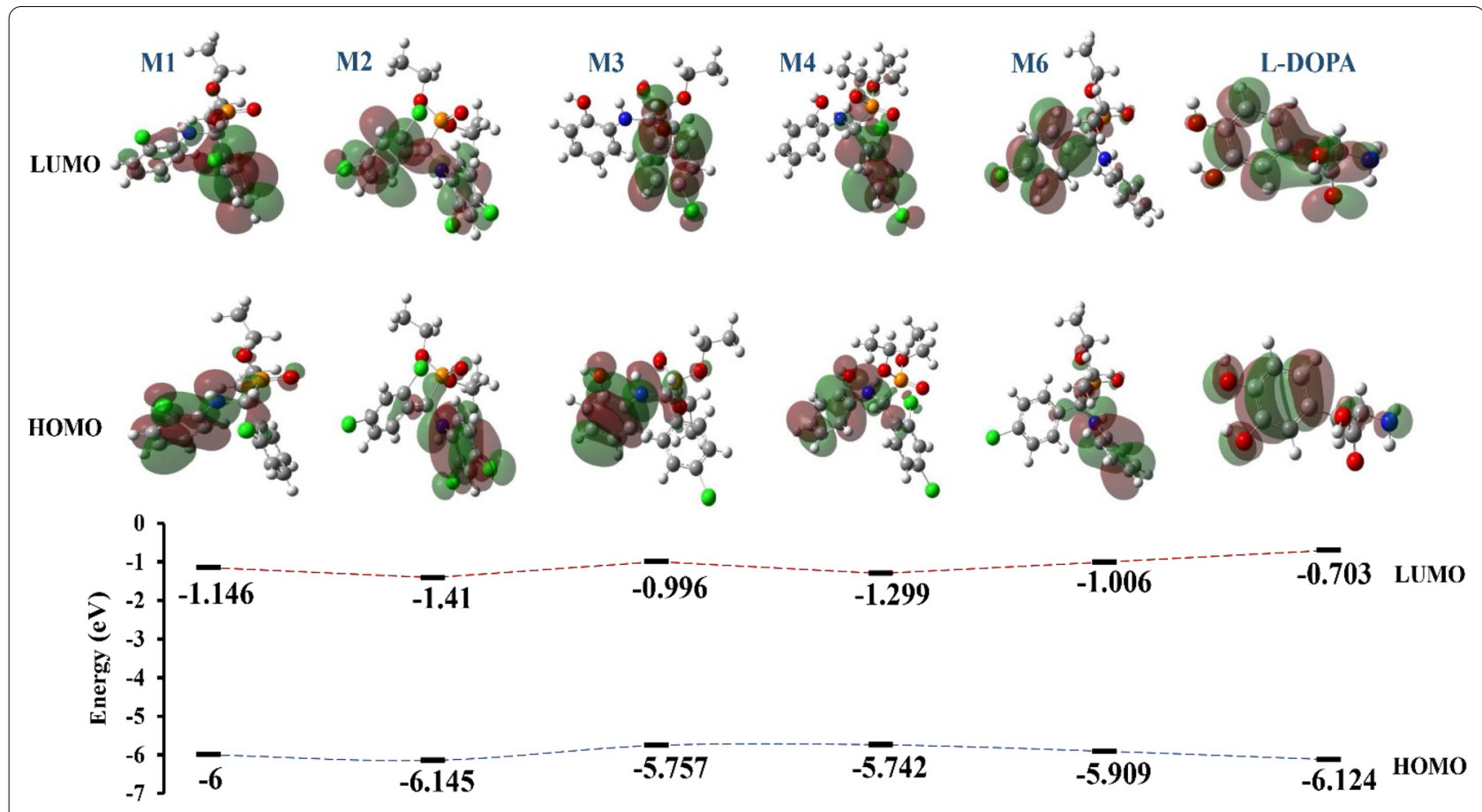

Fig. 6 DFT comparison of M1-M4 and $\mathbf{M 6}$ and L-DOPA. The DFT calculations were carried out with Gaussian 09 software, HOMO and LUMO maps were extracted from GuassView 6.0 program based on the optimized structures

Table 2 Natural atomic charges of the compounds M1-M4 calculated by NBO analysis

\begin{tabular}{llllllllll}
\hline Name & $\mathbf{P}$ & $\mathbf{0 1}$ & $\mathbf{0 2}$ & $\mathbf{0 3}$ & $\mathbf{N}$ & $\mathbf{R} \mathbf{1}$ & $\mathbf{R 2}$ & $\mathbf{R 3}$ & $\mathbf{R}$ \\
\hline $\mathrm{M} 1$ & 2.336 & -1.104 & -0.852 & -0.860 & -0.631 & - & $\mathrm{Cl}(-0.025)$ & - & $\mathrm{Cl}(-0.008)$ \\
M2 & 2.348 & -1.098 & -0.850 & -0.860 & -0.641 & $\mathrm{Cl}(-0.015)$ & $\mathrm{Cl}(-0.005)$ & $\mathrm{Cl}(0.007)$ & $\mathrm{Cl}(0.023)$ \\
M3 & 2.318 & -1.101 & -0.853 & -0.865 & -0.639 & - & $\mathrm{O}(-0.711)$ & $\mathrm{Cl}(-0.018)$ & - \\
M4 & 2.339 & -1.098 & -0.845 & -0.862 & -0.648 & - & $\mathrm{O}(-0.707)$ & $\mathrm{Cl}(0.005)$ & $\mathrm{Cl}(0.005)$ \\
L-DOPA & - & $-\mathbf{0 . 6 9 4}$ & $-\mathbf{0 . 7 1 5}$ & - & $-\mathbf{0 . 8 5 1}$ & - & - & - & -
\end{tabular}

*The natural atomic charges of L-DOPA refers to the nitrogen and oxygen atoms of hydroxyls bonded to the ring 
aniline moiety and the $\mathrm{P}-\mathrm{C}-\mathrm{N}$ bridge in all the compounds (M1-M4, and M6), which refer to the impact of the aniline moiety on their bioactivity. These findings are in agreement with the experimental results that indicated the importance of the aniline moiety substituents on the fungicidal activity. According to the Klopman-Salem equation [37-40], the interaction between two systems (e.g., enzyme and substrate) can be controlled by two major factors, the charges of the interacted atoms and the delocalization position of the frontier molecular orbitals. Thus, we have studied the delocalization of the frontier molecular orbitals of M1-M4 compounds and compared them with the enzyme-substrate L-DOPA. L-3,4-dihydroxyphenylalanine or L-DOPA acts as a substrate for phenol oxidase enzyme $[5,41,42]$. This molecule interacts with the copper-binding region within the enzyme [42-45]. We have investigated the inhibitory activity of our molecules based on their similarity with L-DOPA in the delocalization of the frontier molecular orbitals and charge distribution. As can be seen in Fig. 6, the HOMO orbital delocalized in a suitable section on the aniline moiety and the hydroxyl groups of M3 and M4. However, a tiny section of the HOMO orbital delocalized on the phosphorus and phosphorus-related oxygen atoms in M1 and M2 compounds, which reduces their impact on the compounds' reactivity. Also, compared to L-DOPA $(-6.124 \mathrm{eV})$, the energy of HOMO in M3 and M4 $(-5.757 \mathrm{eV}$ and $-5.742 \mathrm{eV})$ have more differences than the energy of HOMO in M1 and M2 $(-6 \mathrm{eV},-6.145 \mathrm{eV})$. It could be said that the bioactivity is not only orbitalcontrolled in the compounds having phenolic oxygen (M3 and M4) but also is controlled by the atomic charge, as can be indicated in NBO analysis.

\section{Natural population analysis (NPA)}

As can be noted from Table 2, the atomic charges of the phosphorus and oxygen atoms bonded to phosphorus are similar in all molecules (M1-M4), which may indicate that this part is not the primary factor affecting their bioactivity. Both M3 and M4 have $\mathrm{OH}$-substituent on the aniline moiety ( $R_{2}$ substituent); this makes their structure similar to the enzyme-substrate L-DOPA, which has two hydroxyl groups interact with the copper-binding region within the enzyme [42-45]. When Cl-substituent replaces the $\mathrm{OH}$-substituent in $\mathrm{R}_{2}$ in $\mathbf{M} 1$ and $\mathbf{M} 2$, the anti-phenol oxidase activity significantly dropped down. Table 2 displays the small negative charge of the hydroxyl oxygen atoms of both M3 (-0.711) and M4 $(-0.707)$. These charges are almost equal to the charge of hydroxyloxygen atoms in L-DOPA $(-0.715$ and -0.694$)$ (Table 2$)$. It can be concluded that the negative charge of the oxygen atom related to the aniline-hydroxyl group may control the anti-phenol oxidase activity of both M3 and
M4. Phenol oxidase is an essential protein for an insect's immunity and defense, and it is involved in the encapsulation and melanization process as a defense reaction [5, 7-9]. These hydroxyl-related oxygen of M3 and M4 may interact with the copper-binding region within the enzyme active site [42-45] and prevent the melanization process. These theoretical studies displayed the importance of the aniline moiety on the fungicidal activity of our compounds; besides, it showed the impact of charge distribution in their anti-phenol oxidase activity.

\section{Conclusions}

This paper has investigated the dual bioactivity of some $\alpha$-amino phosphonate derivatives. Most of the synthesized compounds revealed a level of fungicidal activity against both Macrophomina phaseolina, and Pythium aphanidermatum especially M4. Both M3 and M4 displayed a good anti-phenol oxidase activity, which may imply their capacity to interfere with the insects immune system. The theoretical study pointed out the role of charge distribution on the phenol oxidase inhibitory activity. It indicated the impact of the aniline moiety substituents on the fungicidal activity. We hope that our compounds will serve as a base for the future to develop novel organophosphorus fungicides with additional insects phenol oxidase inhibitory activity, also; the authors suggest further assays on both target and non-target organisms.

\section{Acknowledgements \\ We are grateful to Ali Mokhtassi-Bidgoli from Department of Agronomy (Tar- biat Modares University) for his support in statistical analysis of this work.}

\section{Authors' contributions}

$M A, K G$, and $A A E V$ participated in the synthesis and characterization of the compounds; MA, NS and MM provided the antifungal and anti-phenol oxidase assays; MA and MB provided the DFT study. MA and NS were the major

contributors in writing the manuscript. All authors read and approved the final manuscript.

\section{Funding}

This work was supported by Tarbiat Modares University, Tehran, Iran.

Availability of data and materials

All data generated or analyzed during this study are included in this article.

\section{Declarations}

Ethics approval and consent to participate

Not applicable.

\section{Consent for publication}

Not applicable.

\section{Competing interests}

The authors declare no conflict of interest. 


\section{Author details}

'Department of Plant Pathology, Faculty of Agriculture, Tarbiat Modares University, P.O.B. 14115-336, Tehran, Iran. ${ }^{2}$ Department of Chemistry, Tarbiat Modares University, P.O. Box 14115-175, Tehran, Iran. ${ }^{3}$ Department of Entomology, Faculty of Agriculture, Tarbiat Modares University, P.O. Box 14115-336, Tehran, Iran. ${ }^{4}$ Department of Chemistry, Islamic Azad University, North Tehran Branch, Tehran, Iran.

\section{Received: 29 March 2021 Accepted: 23 July 2021}

Published online: 27 September 2021

\section{References}

1. Oliver RP, Hewitt HG. Fungicides in crop protection. 2nd ed. Cabi: Wallingford; 2014.

2. Walter $\mathrm{H}$. New fungicides and new modes of action. In Modern fungicides and antifungal compounds VI. 16th International Reinhardsbrunn Symposium, Friedrichroda, Germany, 2014; April 25-29, (2010), 47-54. Deutsche Phytomedizinische Gesellschaft eV Selbstverlag.

3. Morton V, Staub T. A short history of fungicides. APS Net Features. 2008. https://doi.org/10.1094/APSnetFeature-2008-0308.

4. Fest C, Schmidt KJ. The chemistry of organophosphorus pesticides. Berlin: Springer; 2012.

5. González-Santoyo I, Córdoba-Aguilar A. Phenoloxidase: a key component of the insect immune system. Entom Exp Appl. 2012;142(1):1-16.

6. Cerenius L, Söderhäll K. The prophenoloxidase-activating system in invertebrates. Immunol Rev. 2004;198(1):116-26. https://doi.org/10.1111/j. 0105-2896.2004.00116.x.

7. Ashida M, Brey PT. Role of the integument in insect defense: pro-phenol oxidase cascade in the cuticular matrix. Natl Acad Sci. 1995:92(23):10698702. https://doi.org/10.1073/pnas.92.23.10698.

8. Lai SC, Chen CC, Hou RF. Immunolocalization of prophenoloxidase in the process of wound healing in the mosquito Armigeres subalbatus (Diptera: Culicidae). J Med Entomol. 2002;39(2):266-74. https://doi.org/10.1603/ 0022-2585-39.2.266

9. Lu A, Zhang Q, Zhang J, Yang B, Wu K, Xie W, Luan YX, Ling E. Insect prophenoloxidase: the view beyond immunity. Front Physiol. 2014;5:252. https://doi.org/10.3389/fphys.2014.00252.

10. Gholami T, Ghadamyari M, Oliaee AO, Ajamhasani M. Effects of inhibitors on haemolymph phenoloxidase from rosaceous branch borer, Ospheranteria coerulescens (Coleoptera: cerambycidae). J Plant Prot Res. 2013. https://doi.org/10.2478/jppr-2013-0049.

11. Allen JG, Atherton FR, Hall MJ, Hassall CH, Holmes SW, Lambert RW, Nisbet LJ, Ringrose PS. Phosphonopeptides, a new class of synthetic antibacterial agents. Nature. 1978;272(5648):56-8. https://doi.org/10.1038/ $272056 \mathrm{a0}$.

12. Abdou WM, Barghash RF, Bekheit MS. Carbodiimides in the synthesis of enam- ino- and a-aminophosphonates as peptidomimetics of analgesic/ antiinflammatory and anticancer agents. J Arch Pharm Chem Life Sci. 2012;345(11):884-95. https://doi.org/10.1002/ardp.201200142.

13. Devineni SR, Doddaga S, Donka R, Chamarthi NR. CeCl 3 . $7 \mathrm{H} 2 \mathrm{O}-\mathrm{SiO} 2$ : catalyst promoted microwave assisted neat synthesis, antifungal and antioxidant activi-ties of a-diaminophosphonates. Chin Chem Lett. 2013;24(8):759-63. https://doi.org/10.1016/j.cclet.2013.04.037.

14. Kukhar'VP, Hudson HR. Aminophosphonic and aminophosphinic acids: Chemistry and biological activity. Hoboken: Wiley; 2000. p. 660.

15. Kafarski P, Lejczak B. Aminophosphonic acids of potential medical importance. Curr Med Chem Anti Cancer Agents. 2001;1(3):301-12. https://doi. org/10.2174/1568011013354543.

16. Kirby AJ, Warren SG. The organic chemistry of phosphorus (reaction mechanisms in organic chemistry, monograph 5). New York : Elsevier Publishing Co.; 1967. p. 302.

17. Pudovik AN, Konovalova IV. Addition reactions of esters of phosphorus (III) acids with unsaturated systems. Synthesis. 1979;2:81-96. https://doi. org/10.1055/s-1979-28566.

18. Mahdizadeh V, Safaie N, Goltapeh EM. Diversity of Macrophomina phaseolina based on morphological and genotypic characteristics in Iran. Plant Pathol J. 2011;27(2):128-37. https://doi.org/10.5423/PPJ.2011.27.2.128.
19. Kakuei NM, Mahmoudi SB, Norouzi P, Soltani J. Pathogenic variability of Pythium aphanidermatum isolates the causal agent of sugar beet root rot in Iran. Appl Entomol Phytopathol. 2013:80:131-44.

20. Schmitz H. Poisoned food technique. Ind Eng Chem Anal Ed. 1930;2(4):361.

21. Pandey DK, Chandra H, Tripathi NN. Volatile fungitoxic activity of some higher plants with special reference to that of Callistemon lanceolatus DC. J Phytopathol. 1982;105(2):175-82. https://doi.org/10.1111/j.1439-0434. 1982.tb00675.x

22. Mehrparvar M, Goltapeh EM, Safaie N, Ashkani SS, Hedesh RM. Antifungal activity of essential oils against mycelial growth of Lecanicillium fungicola var. fungicola and Agaricus bisporus. Industrial Crops and Products. 2016;84:391-8 https://doi.org/10.1016/j.inderop.2016.02.012

23. Kobno Y, Waanabe M, Hosokawa D. Studies on the physiogical changes in the rice plant infected with Xanthomonas citri. Ann Phytopath Soc Japan. 1981:47:555-61. https://doi.org/10.3186/jjphytopath.47.555.

24. Wu T, Zivanovic S, Draughon FA, Conway WS, Sams CE. Physicochemical properties and bioactivity of fungal chitin and chitosan. J Agric Food Chem. 2005;53(10):3888-94. https://doi.org/10.1021/jf048202s.

25. Hatada Y, Ohta Y, Horikoshi K. Hyperproduction and application of alphaagarase to enzymatic enhancement of antioxidant activity of porphyrin. J Agric Food Chem. 2006;54(26):9895-900. https://doi.org/10.1021/jf061 3684.

26. Ullah I, Khan A, Ali L, Khan A, Waqas M, Lee IJ, Shin JH. An insecticidal compound produced by an insect-pathogenic bacterium suppresses host defenses through phenoloxidase inhibition. Molecules. 2014;19(12):20913-28. https://doi.org/10.3390/molecules191220913.

27. Frisch MJ, Trucks GW, Schlegel HB, Scuseria GE, Robb M A, Cheeseman JR, Scalmani G, Barone V, Mennucci B, Petersson GA, Nakatsuji H, Caricato M, Li X, Hratchian HP, Izmaylov AF, Bloino J, Zheng G, Sonnenberg JL, Hada M, Ehara M, Toyota K, Fukuda R, Hasegawa J, Ishida M, Nakajima T, Honda Y, Kitao O, Nakai H, Vreven T, Montgomery JA, Jr., Peralta JE, Ogliaro F, Bearpark M, Heyd JJ, Brothers E, Kudin KN, Staroverov VN, Keith T, Kobayashi R, Normand J, Raghavachari K, Rendell A, Burant JC, lyengar SS, Tomasi J, Cossi M, Rega N, Millam JM, Klene M, Knox JE, Cross JB, Bakken V, Adamo C, Jaramillo J, Gomperts R, Stratmann RE, Yazyev O, Austin AJ, Cammi R, Pomelli C, Ochterski JW, Martin RL, Morokuma K, Zakrzewski VG, Voth GA, Salvador, Dannenberg JJ, Dapprich S, Daniels AD, Farkas O, Foresman J B, Ortiz JV, Cioslowski J, Fox DJ. Gaussian 09, Revision D.01, Gaussian, Inc., Wallingford CT. (2013).

28. Newton MD. Applications of electronic structure theory. Modern Theor Chem. 1977:4:246-8.

29. Hay PJ, Wadt WR. Ab initio effective core potentials for molecular calculations. Potentials for $\mathrm{K}$ to Au including the outermost core orbitals. J Chem Phys. 1985;82(1):299-310. https://doi.org/10.1063/1.448975.

30. Wadt WR, Hay PJ. Ab initio effective core potentials for molecular calculations. Potentials for main group elements $\mathrm{Na}$ to $\mathrm{Bi}$. J Chem Phys. 1985;82(1):284-98. https://doi.org/10.1063/1.448800.

31. Glendening ED, Reed AE, Carpenter JE, Weinhold F. NBO Version 3.1, Tci. Madison: University of Wisconsin; 1998.

32. SAS 9.3. SAS Institute Inc. Cary, NC, USA. 2011.

33. Wang BL, Zhu HW, Ma Y, Xiong LX, Li YQ, Zhao Y, Zhang JF, Chen YW, Zhou S, Li ZM. Synthesis, insecticidal activities, and SAR studies of novel pyridylpyrazole acid derivatives based on amide bridge modification of anthranilic diamide insecticides. J Agric Food Chem. 2013;61(23):5483-93. https://doi.org/10.1021/jf4012467.

34. Liu XH, Chen PQ, Wang BL, Li YH, Wang SH, Li ZM. Synthesis, bioactivity, theoretical and molecular docking study of 1-cyano-N-substituted-cyclopropanecarboxamide as ketol-acid reductoisomerase inhibitor. Bioorg Med Chem Lett. 2007;17(13):3784-8. https://doi.org/10.1016/j.bmcl.2007. 04.003.

35. Sun NB, Fu JQ, Weng JQ, Jin JZ, Tan CX, Liu XH. Microwave assisted synthesis, antifungal activity and DFT theoretical study of some novel 1, 2, 4-triazole derivatives containing the 1, 2, 3-thiadiazole moiety. Molecules. 2013;18(10):12725-39. https://doi.org/10.3390/molecules181012725.

36. Dannenberg JJ. Using perturbation and frontier molecular orbital theory to predict diastereofacial selectivity. Chem Rev. 1999;99(5):1225-42. https://doi.org/10.1021/cr980382f.

37. Cho JK, Shaik S. Electron transfer vs polar mechanisms. Transition-state structures and properties for reactions of a cation radical and a nucleophile. J Am Chem Soc. 1991;113:9890-1. 
38. Klopman G. Chemical reactivity and the concept of charge-and frontiercontrolled reactions. J Am Chem Soc. 1968;90(2):223-34. https://doi.org/ 10.1021/ja01004a002.

39. Klopman G. The control of chemical reactivity. J Mol Struct. 1983;103:1219. https://doi.org/10.1016/0166-1280(83)85013-1.

40. Salem L. Intermolecular orbital theory of the interaction between conjugated systems. I. General theory. J Am Chem Soc. 1968;90(3):543-52. https://doi.org/10.1021/ja01005a001.

41. Chase MR, Raina K, Bruno J, Sugumaran M. Purification, characterization and molecular cloning of prophenoloxidases from Sarcophaga bullata. Insect Biochem Mol Bio. 2000;30(10):953-67. https://doi.org/10.1016/ S0965-1748(00)00068-0.

42. Sugumaran M. Unified mechanism for sclerotization of insect cuticle. Adv Insect Physiol. 1998;27:229-334. https://doi.org/10.1016/S0065-2806(08) 60014-4.
43. Sugumaran M. Comparative biochemistry of eumelanogenesis and the protective roles of phenoloxidase and melanin in insects. Pigment Cell Res. 2002;15(1):2-9. https://doi.org/10.1034/j.1600-0749.2002.00056.x.

44. Li Y, Wang $Y$, Jiang $H$, Deng J. Crystal structure of Manduca sexta prophenoloxidase provides insights into the mechanism of type 3 copper enzymes. Proc Natl Acad Sci. 2009;106(40):17002-6. https://doi.org/10. 1073/pnas.0906095106.

45. Decker H, Schweikardt T, Tuczek F. The first crystal structure of tyrosinase: all questions answered? Angw Chem Int Ed. 2006;45(28):4546-50. https:// doi.org/10.1002/anie.200601255.

\section{Publisher's Note}

Springer Nature remains neutral with regard to jurisdictional claims in published maps and institutional affiliations.

\section{Submit your manuscript to a SpringerOpen ${ }^{\circ}$ journal and benefit from:}

- Convenient online submission

- Rigorous peer review

- Open access: articles freely available online

- High visibility within the field

- Retaining the copyright to your article

Submit your next manuscript at $\boldsymbol{\nabla}$ springeropen.com 